\title{
Risk assessment in the Netherlands
}

\author{
Citation for published version (APA):
}

de Ruiter, C. (2016). Risk assessment in the Netherlands. In J. Singh, S. Fazel, \& S. Bjorkly (Eds.), International perspectives on violence risk assessment (pp. 270-279). Oxford University Press.

Document status and date:

Published: 01/01/2016

Document Version:

Publisher's PDF, also known as Version of record

\section{Document license:}

Taverne

\section{Please check the document version of this publication:}

- A submitted manuscript is the version of the article upon submission and before peer-review. There can be important differences between the submitted version and the official published version of record.

People interested in the research are advised to contact the author for the final version of the publication, or visit the DOI to the publisher's website.

- The final author version and the galley proof are versions of the publication after peer review.

- The final published version features the final layout of the paper including the volume, issue and page numbers.

Link to publication

\footnotetext{
General rights rights.

- You may freely distribute the URL identifying the publication in the public portal. please follow below link for the End User Agreement:

www.umlib.nl/taverne-license

Take down policy

If you believe that this document breaches copyright please contact us at:

repository@maastrichtuniversity.nl

providing details and we will investigate your claim.
}

Copyright and moral rights for the publications made accessible in the public portal are retained by the authors and/or other copyright owners and it is a condition of accessing publications that users recognise and abide by the legal requirements associated with these

- Users may download and print one copy of any publication from the public portal for the purpose of private study or research.

- You may not further distribute the material or use it for any profit-making activity or commercial gain

If the publication is distributed under the terms of Article $25 \mathrm{fa}$ of the Dutch Copyright Act, indicated by the "Taverne" license above, 


\section{International Perspectives \\ on Violence Risk Assessment}

Edited by

Jay P. Singh

Stål Bjorkly

Seena Fazel

\section{OXFORD}




\title{
Anriericam Psychology-Law Society series
}

\author{
Series Editor" \\ Patricia A. Zapf \\ Edirorial Board \\ Gail S. Goodman \\ Thomas Grisso \\ Craig Haney \\ Kirk Heilbrun \\ Jolun Monahan \\ Marlene Morett \\ Edward P. Mulvey \\ J. Don Read \\ N. Dickon Reppucci \\ Ronald Roesch \\ Gary L. Wells \\ Lawrence S. Wrightsman \\ Books in the Series \\ Trial Consulting \\ Any I. Posey \\ and Lawrence S. Wrightsman \\ Death by Design! \\ Craig Haney \\ Psychological Injuries \\ William J. Koch, Kevin S. Douglas, \\ Tonia L. Nicholls, \\ and Melanie L. O'Neill \\ Emergency Department Treatment of \\ the Psychiatric Patient \\ Susan Stefan \\ The Psychology of the Supreme Court \\ Lawrence S. Wrightsman \\ Proving the Unprovable \\ Christopher Slobogin \\ Adolescents, Media, and the Law \\ Roger J.R. Levesque \\ Oral Arguments Before \\ the Supreme Court \\ Lawrence S. Wrightsman \\ God in the Courtroom \\ Brian H. Bornstein and Monica K. Miller \\ Expert Testimony on the Psychology \\ of Eyewitness Identification \\ Lidited by Brian L. Culler \\ The Psychology of Judicial \\ Decision-Making \\ Edited by David KIcin \\ and Gregory Mitchell
}

The Miranda Ruling: Its Past, Present, and Future

Lawrence S. Wrightsman

and Mary L. Pitman

Juveniles at Risk: A Plea

for Preventive Justice

Christopher Slobogin

and Mark R. Fondacaro

The Ethics of Total Confinement

Bruce A. Arrigo, Heather Y. Bersot, and Brian G. Sellers

International Human Rights and. Mental Disability Law

Michael L. Perlin

Applying Social Science to Reduce

Violent Offending

Edited by Joel Dvoskin,

Jennifer L. Skeem, Raymond W. Novaco, and Kevin S. Douglas

Children Who Resist Postseparation

Parental Contact

Barbara Jo Fidler, Nicholas Bala,

and Michael A. Saini

Trauma, Stress, and Wellbeing in

the Legal System

Edited by Monica K. Miller

and Brian H. Bornstein

psychology, Law, and the Wellbeing of Children

Edited by Monica K. Miller,

Jared C. Chamberlain, and Twila Wingrove

Murder in the Courtroom: The Cognitive Neuroscience of Extreme Violent

Behavior

Brigitte Vallabhajosula

Rational Suicide, Irrational

Laws: Examining Current Approaches

to Suicide in Policy and Law

Susan Stefan

International Perspectives on Violence

Risk Assessment

Edited by Jay P. Singh, Stål Bjørkly, and Seena Fazel 
Corine de Ruiter

This chapter reviews the history and current state of affairs concerning risk assessment in the Netherlands, with a particular emphasis on the adult forensic mental health system and the Terbeschikkingstelling (TBS) order. The role of risk assessment in the probation service, outpatient forensic settings, and adolescent forensic psychiatry is also discussed briefly. Dutch forensic mental health professionals belong to the "early adopters" of structured risk judgment (SPJ) tools, which has led to their prolific use but possibly also to some inadvertent side effects. Recently, Dutch researchers have developed structured tools for the assessment of protective factors (e.g., Structured Assessment of PROtective Factors [SAPROF]; de Vogel, de Ruiter, Bouman, \&u de Vries Robbé, 2009) to complement the assessment of risk factors, which fits well within the tradition of humane and rehabilitative treatment of mentally disordered offenders in the Netherlands.

\section{The Dutch Legal Framework}

The Dutch Entrustment Act (in Dutch: Beginselenweg verpleging ter beschikking gestelden of 1997), was originally enacted in 1928 (van Marle, 2002). Its goal was to protect society from individuals who had committed a serious crime on account of a serious mental disorder or defective development (including a personality disorder or serious intellectual disability), and who were believed to constitute a continuing danger to society. In general, a TBS order is combined with mandatory treatment (Art. 37b, $\$ 1$ Dutch Code of Criminal Law [CCL]). The law requires that at least two experts from 
different disciplines report on the defendant before the trial court can issue a TBS order. A judge can impose a TBS order if the following conditions apply (Art. 37a CCL): (a) the defendant must suffer from a mental disorder, which means his responsibility for the alleged crime is (severely) diminished or absent; (b) the crime carries a prison sentence of at least 4 years, and (c) there is a risk for the safety of other people or for the general safety of persons or goods.

A TBS order results in involuntary admission to a specialized maximumsecurity forensic psychiatric hospital (Art. 37d, \$1 CCL) aimed at motivating the patient to participate in the hospital's treatment programs. Forensic patients detained under TBS legislation in general have been convicted for serious violent and sexual offenses (for further discussion of the TBS system, see de Ruiter and Hildebrand [2003] and de Ruiter and Petrila [2016]).

The Netherlands has a dualistic sanctioning system. Punitive sanctioning takes place when a defendant is considered guilty of the crime and is also deemed culpable. Coercive measures, such as the TBS order, can be used when the defendant is guilty and also considered high risk and not fully culpable. The choice between punishment and coercive measures is determined by the judge, based on the degree of responsibility of the defendant. Article $37 \mathrm{a}$ of the CCL creates the possibility of diminished responsibility. On the basis of this legal statute, more refined "degrees" of criminal responsibility were introduced in the Dutch jurisprudence and, eventually, a 5-point scale emerged that indicates the degree of criminal responsibility: full responsi bility, slightly diminished responsibility, diminished responsibility, severely diminished responsibility, and total absence of responsibility. For example, if a person committed a first-degree murder while experiencing an episode of paranoid psychosis and the trial court consequently considers this person to have diminished responsibility for the offense, the court can sentence him to a long (e.g., 15 years, which is considered long in the Netherlands) prison sentence in combination with a TBS order. In this case, the prison sentence is executed first; after the prison term is served, the person is transferred to a forensic hospital. In theory, and sometimes also in practice, a person found guilty but with diminished responsibility can serve the same prison term as it fully responsible defendant and face an additional period of involuntary hospitalization beyond the prison term. Common-law systems in general have fewer "degrees" of criminal responsibility. Also, in contrast to common-law systems, a diminished degree of responsibility in the Dutch legal system is not restricted to a list of sanctioned diseases and disorders. Thus, antisocial personality disorder may be a reason for diminished responsibility in the Netherlands (de Ruiter \& Petrila, 2016).

All 13 Dutch forensic psychiatric hospitals that admit TBS patients use at cognitive-behavioral approach to treatment. Patients live in a secure setting, with units housing around 12 patients. Whenever possible, from a risk management perspective, patients are allowed a degree of freedom of movement inside the hospital. During the first 8 weeks after admission, a structured 
violence risk assessment is conducted for every patient, using validated risk assessment tools such as the Historical-Clinical-Risk Management 20 and focuses on diminishing dynamic risk fant and risk management plan that patients with personality disorders, these for violence is formulated. For lack of empathy, deficient coping skill, factors may include impulsivity, cudes. For patients with psychotic disord and hostile and/or antisocial attisions and hallucinations, a lack of insight into their illness, and problems
with substance use (de Ruiter \& Petrila in

\section{Mistory of Violence Risk Assessment in the Netherlands}

Structured violence risk assessment tools were introduced into the Dutch forensic mental health system during the late 1990s (de Ruiter \& Hildebrand, 2003, 2007). Before then, risk assessments were performed on the basis of instructured clinical judgment, which have been shown to be unreliable and Bos, \& van de Ven, the Dutch TBS context (de Vogel, de Ruiter, Hildebrand, 2006). Tools stemming from the SPI aeter, van der Staak, \& van den Brink, sic psychiatry from the start, because the and are, thus, suitable to meause these tools contain dynamic risk factors arial tools, which consist mostly of static, his risk level, in contrast to actuextension of liberties, such patients under the TBS or as supervised or unsupervised leave for forensic Since January 1,2008, all requests for be forwarded to the Ministry of Justice. Advisory Board (in Dutch, Adviescollege Verloftomined by the Leave Review at least nine forensic psychologists/psychiatrists, at least three jurists, and submitted according to a sisk assessment. The request to the AVT has to be ing the use of

Theoretically a T'B risk assessment tools and reporting (see Box 18.1). Initially imposed for 2 years (is of indefinite duration (Article 38e, \$2 CCL). 1 - or 2 -year periods as the courticle 38d, $\$ 1 \mathrm{CCL}$ ), it may be extended for the risk to society is the court reevaluates the patient to determine whether base their advice to the high (Article 38d, $\$ 2 \mathrm{CCL}$ ). Forensic hospitals order by means of structurt on the extension (or termination) of the TBS made to the AVT. The type risk assessments, highly similar to the requests is from supervised to typical progression of patients under the TBS order to unsupervised leave, leading up to the "transmural" still closely supervised by hoave, the patient lives outside the hospital but is ducted at each point an extension of the patient's libk assessments are conin case no extension is foreseen risk asestient's liberties is contemplated; every 6 months If the patient breaches a condition he to be repeated at least 


\section{Box 18.1 Risk Assessment in Requests for Leave for Forensinic} Psychiatric Patients under Terbeschikkingstelling Lawy

Risk assessment has to be performed by means of evidence-based instruments such as the Historische, Klinische, Toekomstige-30 (HKT30), the Historical-Clinical-Risk Management20, the Sexual Violence Risk-20, and the Psychopathy Checklist-Revised. The HKT-30 is a structured risk assessment tool that was developed in the Netherlands. It consists of 30 items (11 historical, 13 clinical and dynamic, and 6 future) scored on a 5-point scale (Werkgroep Risicotaxatie Forensische Psychiatrie, 2002). A multidisciplinary consensus on the interpretation and weighing of risk is important. Furthermore, specific attention needs to be paid to the following combination of risk items of the HKT30: impulsivity, substance use, attitudes toward intervention, hostility, violation of conditions, social skills, and coping skills. It is mandatory to follow the manuals of the mentioned instruments. This means, for instance, that items must be judged in relation to their interaction with other items. The document should explain how risk will be managed toward an acceptable level via a risk management plan. When a high degree of psychopathy is present (i.e., a score of 26 points or more on the Psychopathy Checklist-Revised), a description of the underlying factors is required.

to the hospital. Reintegration into society is gradual and the patient is assisted in finding work and leisure activities, and building a social network. The usual road to termination of the TBS order is via conditional discharge, with supervision from the probation service. Since September 2010, the conditional phase can last up to 9 years (de Ruiter \& Petrila, in press).

\section{Inadvertent Effects of Structured Risk Assessment}

Since the implementation of structured risk assessment instruments in the Dutch forensic mental health system, the average duration of the treatment phase under the TBS order has increased from 4.2 years for those terminated in 1990 to 8.4 years in 2008 (Nagtegaal, van der Horst, \& Schönberger, 2011).

Nagtegaal et al. (2011) offer a number of plausible explanations for this development, although a causal relationship can obviously not be inferred. Dutch society in general has become more risk averse and "tough on crime" in recent decades (Boutellier, 2005). Also, in 2004 and 2005, several cases of TBS patients who committed serious offenses during granted leaves received extensive media coverage, and this resulted in repeated critical debates in parliament about the workings of the TBS system. In 2005, the Parliamentary Committee Visser was installed with the task of investigating how the 'TBS 
system could be improved to safeguard society against mentally disordered offenders. The report of the Committee Visser (2006) contained 17 recommendations for improvement, a number of which were related to stricter release decision making, which ultimately resulted in the creation of the AVT in 2008 .

The use of structured risk assessment instruments is subject to a number of shortcomings. These instruments have been tested empirically at the group level, but a number of scholars have argued they are not actually well suited to predict reoffending at the individual level (Cooke \& Michie, 2011; Hart, Michie, \& Cooke, 2007; Singh, Fazel, Gueorguieva, \& Buchanan, 2014). "Figh risk" has been shown to have a different meaning, in terms of the objective probability of recidivism, in different samples (Singh et al., 2014). "High," "moderate," and "low" risk most probably also have varying meanings for different mental health professionals and for different legal decision makers (see, for example, Hilton, Carter, Harris, and Sharpe [2008]). Furthermore, most forensic mental health professionals in the Netherlands receive onetime, on-the-job training in the use of risk assessment tools, without any continuing education (Nagtegaal et al, 2011).

\section{Rilisls Assessmemit in ovther Forensic Settings}

A number of other forensic fields in the Netherlands have implemented structured risk assessment tools, largely as a result of the adoption of the risk-need-responsivity model (Andrews \& Bonta, 2003) by the Ministry of Justice during the late 1990 s. For offender rehabilitation to be consistent with the risk-need-responsivity model, knowledge of the offender's risk level and criminogenic needs is essential (e.g., Andrews \& Bonta, 2003; Ogloff \& Davis, 2004). The Dutch Probation Service commissioned the development of a new risk assessment tool titled the Recidive Inschattings Schalen (Recidivism Assessment Scales, or RISc; Adviesbureau Van Montfoort \& Reclassering Nederland, 2004) that fulfilled the twin goals of allowing more integrated services between prison and probation staff while also ensuring all probation officers assessed risk in the same manner. The aim of the RISc is to provide a common, efficient, and effective offender risk and needs assessment system that enables the prison and probation service to achieve targets for reduction in reoffending/reconviction rates, and to provide increased protection to the priblic. Several studies of the reliability (van der Knaap, Leenarts, Born, \& Oosterveld, 2012) and predictive validity for general recidivism (van der Knaap \& Alberda, 2009) of the RISc have been conducted. Most recently, Hildebrand, Hol, and Bosker (2013) demonstrated that a selection of only 17 itrms from the total 61 RISc items was sufficient to predict probation violation (area under the curve $[A U C]=.73$ ).

A nother risk assessment instrument used by the Dutch Probation Service and by several outpatient (forensic) mental health clinics is the Brief Spousal 
Assault Form for the Evaluation of Risk (B-SAFER; Kropp, Hart, \& Belfrage, 2005). The implementation of the B-SAFER resulted from the finding that the RISc did not predict adequately intimate partner violence reoffending in a sample of 100 probationers, whereas the B-SAFER did (Reclassering Nederland, 2012) (. Subsequent studies have documented the relevance of the B-SAFER in determining subtypes of spousal assaulters in both probation and general mental health settings (Serie, van Tilburg, van Dam, \& de Ruiter, 2015; Thijssen \& de Ruiter, 2011).

Violence risk assessment instruments have also been implemented systematically in the Dutch juvenile forensic mental health system. More specifically, the Structured Assessment of Violence Risk in Youth (Borum, Bartel, $8 x$ Forth, 2002) is the instrument of choice when juvenile justice institutions prepare a request to the Ministry for an increase of liberties for a juvenile (Ministry of Justice, 2014). In a study of 117 violent juvenile offenders, we found that unstructured clinical judgment predicted violent reoffending at 3 -years of follow-up at a chance level $(A U C=.45)$ whereas the Structured Assessment of Violence Risk in Youth summary risk judgment showed significant predictive accuracy (AUC $=.71$ [Lodewijks, Doreleijers, \& de Ruiter, 2008]).

Although risk assessment tools have taken a prominent position in the management of risk for those individuals who have already been sentenced, the use of these tools in presentencing forensic mental health evaluations is still highly dependent on the mental health expert who performs the evaluation. A recent study of the quality of pretrial forensic mental health reports on juveniles from the years 2005 to 2007 (Duits, van der Hoorn, Wiznitzer, Wettstein, \& de Beurs, 2012) showed a standardized quality rating of around 6 points on a scale from 1 to 10 points, with one of the shortcomings being insufficient information on risk assessment and management.

\section{Recent Developments and Future Outllook}

The implementation of structured risk assessment tools in the Dutch forensic mental health system during the late 1990 s met with some hesitation and, sometimes, even outright resistance from clinical staff: "Their reluctance was echoed in a thought-provoking paper by Rogers (2000), who claimed that an overreliance on risk factors could result in pessimism among therapists, stigmatization of offenders/patients, and, ultimately, in a too-lengthy detention of forensic psychiatric patients. At about the same time, we started to develop a new tool for protective factors (i.e., SAPROF [de Vogel et al., 2009]) to enhance the assessment of risk of future (sextually) violent behavior with instruments such as the Historical-Clinical-Risk Management20 and Sexual Violence Risk-20. The SAPROF is divided into three subscales: internal items, motivational items, and external items. Initial 
studies have shown good predictive validity of the SAPROF for desistance from violence after discharge from clinical treatment in TBS patients at shortto medium-term follow-up (1-year AUC $=.85,3$-year $\mathrm{AUC}=.75)$ as well as at long-term follow-up (11-year AUC $=.73$ ) (de Vries Robbé, de Vogel, \& de Spa, 2011). Independent studies conducted in the United Kingdom found that the SAPROF was able to predict inpatient violence $(A U C=.85)$ and self-harm (AUC $=.77$ ) (Abidin et al., 2013), as well as discharge from forensic psychiatric treatment (AUC $=.81$ (Davoren et al., 2013). The ShortTerm Assessment of Risk and Treatability (START; Webster, Martin, Brink, Nicholls, \& Desmarais, 2009) is another instrument that contains protective or strength factors that has been implemented successfully in Dutch forensic psychiatry. The START is intended for short-term risk assessment (days to months) and treatment planning for diverse adverse outcomes (suicide, self-harm, violence, substance abuse, self-neglect, victimization) that can arise when caring for individuals with mental disorders. The START comprises 20 items, each evaluated concerning their strength and vulnerability property for the actual person. Troquete et al. (2015) found support for the predictive validity of the START in outpatient forensic psychiatry at 3 months and 6 months follow-up, although AUC values were lower than those found in previous studies with the START in inpatient and research settings (e.g., Wilson, Desmarais, Nicholls, \& Brink, 2010).

Evidently, structured risk assessment tools-and SPJ instruments in particular--have gained a prominent position in Dutch forensic mental health services during the past decade. Furthermore, a strong tradition of empirical validation research on violence risk assessment has emerged in the Netherlands. Dutch scholars have also been leading in the development of novel risk assessment tools, such as the SAPROF and the Female Additional Manual (de Vogel, de Vries Robbé, van Kalmthout, \& Place, 2011). This has formed a strong foundation to move on to new research questions and new paradigms beyond psychometric predictive validity studies. Studies into the effectiveness of risk management strategies based on structured risk assessment instruments are still scarce (de Ruiter \& Nicholls, 2011), as are studies of the most effective ways of risk communication (for an overview of this literature, see de Ruiter and Kaser-Boyd [2015]). Future innovative research in the Netherlands and abroad will hopefully bring the use of structured risk assessment tools to the next level.

\section{Treferences}

Abidin, Z., Davoren, M., Naughton, L., Gibbons, O., Nulty, A., \& Kennedy, H. G. (2013). Susceptibility (risk and protective) factors for in-patient violence and self-harm: Prospective study of structured professional judgement instruments START and SAPROF, DUNDRUM-3 and DUNDRUM-4 in forensic mental health services. BMC Psychiatry, 13, 197. 
Beginselenwet verpleging ter beschikking gestelden en overige verpleegden strafrechtstoepassing en daarmede verband houdende wijzigingen van het Wetboek van Strafrecht en de Beginselenwet gevangeniswezen (1997).

Borum, R., Bartel, P., \& Forth, A. (2002). Manual for the Structured Assessment of Violence Risk in Youth (SAVRY), consultation edition, Version 1. Tampa: University of South Florida.

Adviesbureau Van Montfoort \& Reclassering Nederland. (2004). RISc versie 1.0: Recidive Inschattings Schalen: Handleiding [RISc version 1.0: Recidivism assessment scales: Manual]. Utrecht: Reclassering Nederland.

Andrews, D. A., \& Bonta, J. (2003). The psychology of criminal conduct (5th ed.). Cincinnati, $\mathrm{OH}$ : Anderson.

Boutellier, H. (2005). De veiligheidsutopie: Hedendaags onbehagen en verlangen rond misdaad en straf [The safety utopia: Present-day distress and desire surrounding crime and punishment]. The Hague: Boom Legal Publishers.

Committee Visser. (2006). TBS, vandaag over gisteren en morgen [TBS, today about yesterday and tomorrow] [Online]. Available: https://www. eerstekamer.nl/behandeling/20060516/eindrapport_tbs_vandaag_over.

Cooke, D. J., \& Michie, C. (2011). Violence risk assessment: Challenging the illusion of certainty. In B. McSherry \& P. Keyzer (Eds.), Dangerous people: Policy, prediction and practice (pp. 147-161). Oxford, UK: Routledge.

Davoren, M., Abidin, Z., Naughton, I., Gibbons, O., Nulty, A., Wright, B., \& Kennedy, H. G. (2013). Prospective study of factors influencing conditional discharge from a forensic hospital: The DUNDRUM-3 programme completion and DUNDRUM-4 recovery structured professional judgement instruments and risk. BMC Psychiatry, 13, 185.

de Ruiter, C., \& Hildebrand, M. (2003). The dual nature of forensic psychiatric practice: Risk assessment and management under the Dutch TBS-order, In P. J. van Koppen \& S. D. Penrod (Eds.), Adversarial vs. inquisitorial justice: Psychological perspectives on criminal justice systems (pp. 91-106). New York, NY: Plenum Press.

de Ruiter, C., \& Hildebrand, M. (2007). Risk assessment and treatment in Dutch forensic psychiatry. Netherlands Journal of Psychology, 63, 166-175.

de Ruiter, C., \& Nicholls, T. L. (2011). Protective factors in forensic mental health: A new frontier. International Yournal of Forensic Mental Health, 10, $160-170$.

de Ruiter, C., \&z Kaser-Boyd, N. (2015). Forensic psychological assessment in practice: Case studies. New York, NY: Routledge.

de Ruiter, C., \& Petrila, J. (in press). TBS in the Netherlands. In B. Puri \& I. Treasaden (Eds.), Forensic psychiatry. London, UK: Taylor and Francis.

de Vogel, V., de Ruiter, C., Bouman, Y., \& de Vries Robbé, M. (2009). SAPROF: Guidelines for the assessment of protective factors for violence risk. Utrecht: Forum Educatief. [English version of the Dutch original].

de Vogel, V., de Ruiter, C., Hildebrand, M., Bos, B., \& van de Ven, P. (2004). Type of discharge and risk of recidivism measured by the $\mathrm{HCR}-20$ : A retrospective study in a Dutch sample of treated forensic psychiatric patients. Interrational Journal of Forensic Mental Health, 3, 149-165.

de Vogel, V., de Vries Robbé, M, van Kalmthout, W., \& Place, C. (2011). Female Additional Manual (FAM): Additional guidelines to the HCR-20 for assessing risk for violence in women. Utrecht: Van der Hoeven Kliniek. 
de Vries Robbé, M., de Vogel, V., \& de Spa, E. (2011). Protective factors for violence risk in forensic psychiatric patients. A retrospective validation study of the SAPROF. International Journal of Forensic Mental Health, 10, 178-186.

Duits, N., van der Hoorn, S., Wiznitzer, M., Wettstein, R. M., \& de Beurs, E. (2012). Quality improvement of forensic mental health evaluations and reports of youth in the Netherlands. International Journal of Law and Psychiatry, 35, 440-444.

Hart, S. D., Michie, C., \& Cooke, D. J. (2007). Precision of actuarial risk assessment instruments: Evaluating the "margins of error" of group v. individual predictions of violence. The British Joumal of Psychiatry, 190, $s 60-s 65$.

Hildebrand, M., Hol, A. M., \& Bosker, J. (2013). Predicting probation supervision violations. Psychology, Public Policy, and Law, 19, 114-125.

Hilton, N. Z., Carter, A., Harris, G., \&r Sharpe, A. (2008). Does using nounumerical terms to describe risk aid violence risk communication? Journal of Interpersonal Violence, 23, 171-88.

Kropp, P. R., Hart, S. D., \& Belfrage, H. (2005). The Brief Spousal Assault Form for the Evaluation of Risk (B-SAFER): User manual. Vancouver: ProActive ReSolutions.

Lodewijks, H. P. B., Doreleijers, T. A. H., \& de Ruiter, C. (2008). SAVRY risk assessment in relation to sentencing and subsequent recidivism in a Dutch sample of violent juvenile offenders. Criminal Justice and Behavior, 35, 696-709.

Ministry of Justice. (2014). Regeling verlof en Scholings-en TrainingsPlan jeugdigen [Leave regulations, and education and training plan for juveniles] [Online]. The Hague: DJI. Available: http://wetten.overheid.nl/BWBR0035001/ geldigheidsdatum_27-01-2015.

Nagtegaal, M. H., van der Horst, R. P., \& Schönberger, H. J. M. (2011). Inzicht in de verblijfsduur van tbs-gestelden: Cijfers en mogelijke verklaringen [Length of stay in forensic psychiatric hospitals: Numbers and possible explanations]. Research and policy series 290. The Hague: Ministry of Security and Justice \& Meppel, Boom Legal Publishers.

Ogloff, J. R. P., \& Davis, M. R. (2004). Advances in offender assessment and rehabilitation: Contributions of the risk-needs-responsivity approach. Psychology, Crime of Law, 10, 229-242.

Philipse, M. W. G., Koeter, M. W. J., van der Staak, C. P. F., \& van den Brink, W. (2006). Static and dynamic patient characteristics as predictors of criminal recidivism: A prospective study in a Dutch forensic psychiatric sample. Law and Human Behavior, 30, 309-327.

Reclassering Nederland (2012). B:SAFER: Informatie voor opdrachtgevers. [Online]. Available: www.reclassering.n1/documents/Bibliotheek/2012/ documenten/120904_B_Safer_3RO_def.pdf

Rogers, R. (2000). The uncritical acceptance of risk assessment in forensic practice. Law and Human Behavior, 24, 595-605.

Serie, C. M. B., van Tilburg, C. A., van Dam, A., \& de Ruiter, C. (2015). Spousal assaulters in outpatient mental health care: The relevance of structured risk assessment. Journal of Interpersonal Violence. Online First. 
Singh, J. P., Fazel, S., Gueorguieva, R., \& Buchanan, A. (2014). Rates of violence in patients classified as high risk by structured risk assessment instruments. The British Journal of Psychiatry, 204, 180-187.

Thijssen, J., \& de Ruiter, C. (2011). Identifying subtypes of spousal assaulters using the B-SAFER. Journal of Interpersonal Violence, 26, 1307-1321.

Troquete, N. A. C., van den Brink, R. H. S., Beintema, H., Mulder, T., van Os, T. W. D. P., Schoevers, R. A, \& Wiersma, D. (2015). Predictive validity of the Short-Term Assessment of Risk and Treatability for violent behavior in outpatient forensic psychiatric patients. Psychological Assessment, 27, 377-391.

van der Knaap, L. M., \& Alberda, D. L. (2009). De predictieve validiteit van de Recidive Inschattings Schalen (RISc) [Predictive validity of the Recidivism Risk Assessment Scales (RISc)]. The Hague: WODC.

van der Knaap, L. M., Leenarts, L. E. W., Born, M. P., \& Oosterveld, P. (2012). Reevaluating interrater reliability in offender risk assessment. Crime 8 Delinquency, 58, 147-163.

van Marle, H. J. C. (2002). The Dutch Entrustment act (TBS): Its principles and innovations. International Journal of Forensic Mental Health, 1, 83-92.

Webster, C. D., Martin, M. L., Brink, J., Nicholls, T. L., \& Desmarais, S. (2009). Manual for the Short-Term Assessment of Risk and Treatability (START): Version 1.1. Port Coquitlam, BC: Forensic Psychiatric Services Commission and St. Joseph's Healthcare.

Werkgroep Risicotaxatie Forensische Psychiatrie. (2002). Handleiding HKT-30 versie 2: Risicotaxatie in de forensische psychiatrie [Manual HKT-30 version 2]. The Hague: Ministry of Justice.

Wilson, C. M., Desmarais, S. L., Nicholls, T. L., \& Brink, J. (2010). The role of client strengths in assessments of violence risk using the Short-Term Assessment of Risk and Treatability (START). International Journal of Forensic Mental Health, 9, 282-293. 